\title{
Phenotypic and quantitative relationship of red cell acid phosphatase with haemoglobin, haptoglobin, and G6PD phenotypes
}

\author{
N SAHA AND N PATGUNARAJAH \\ From the Faculty of Medicine, University of Khartoum, Khartoum, Sudan
}

SUMMARY The phenotypic and quantitative relationship of red cell acid phosphatase with haemoglobin, haptoglobin, and G6PD phenotypes was investigated in three populations in the Sudan and one population in Nilgiris, India. No significant consistent association of red cell acid phosphatase phenotypes was observed with these polymorphisms. However, there was a lack of acid phosphatase $A B$ in G6PD deficient subjects from Nilgiris. The relative quantitative expression of red cell acid phosphatase genes $\mathrm{P}^{\mathrm{A}}, \mathrm{P}^{\mathrm{B}}$, and $\mathrm{P}^{\mathrm{C}}$ was $1 \cdot 0,1 \cdot 2$, and $1 \cdot 3$, respectively, The red cell acid phosphatase activity was higher $(15 \%)$ in the presence of raised haemoglobin $\mathrm{A}_{2}$ and in sickle cell anaemia $(21 \%)$. Those with $\mathrm{Hp}^{2}$ had $18 \%$ higher level of acid phosphatase than those with $\mathrm{Hp}^{1}$. G6PD deficient subjects had a lower level of acid phosphatase activity (20\%) than those with normal G6PD activity.

It has been postulated that the prevalence of certain genes, like the sickle cell, thalassaemia, and glucose6-phosphate dehydrogenase (G6PD) genes, is of selective importance in human populations. ${ }^{12}$ This suggests that the deleterious or lethal effects of these genes in a homozygous state are balanced by some advantage offered by the heterozygous state. There may be some regional variations in the type and extent of these selective factors in different populations. ${ }^{3}$ Red cell acid phosphatase, which is controlled by three common co-dominant alleles $\mathbf{P A}, \mathbf{P},{ }^{\mathbf{B}}$ and $\mathrm{PC}^{\mathrm{C}}$ at an autosomal locus, has been reported to be polymorphic in man. ${ }^{4}$ The enzyme activity of the gene dosage of these three alleles is in the increasing order $\mathbf{P}^{\mathrm{A}},<\mathrm{P}^{\mathrm{B}}, \quad<\mathbf{P C}^{\mathbf{5}}{ }^{6}$ Recently, an interesting association of red cell acid phosphatase, G6PD deficiency with favism, and past incidence of malaria has been reported in Sardinians and Romans. ${ }^{7-9}$ The data suggested that the susceptibility of the subjects to haemolytic manifestations was highest in those carrying the acid phosphatase genes $\mathrm{PC}$ and $\mathrm{PA}$. However, Modiano et $a l^{10}$ reported a lack of association of red cell acid phosphatase phenotypes with past malarial morbidity in the same populations.

The precise functional significance of red cell acid phosphatase is not known. G6PD deficient Caucasian subjects of the Mediterranean type have been Received for publication 11 September 1980 reported to have decreased red cell acid phosphatase activity. ${ }^{11-13}$ However, later studies in Sardinians did not confirm this. ${ }^{614} \beta$-thalassaemia can be responsible for an increased red cell activity. ${ }^{6}$ Negro G6PD deficient subjects had normal levels of acid phosphatase. ${ }^{11}$

\section{Material and methods}

In the course of population genetic studies in the Sudan and Nilgiris, India, data were collected on the phenotypic distribution of red cell acid phosphatase, haemoglobin, haptoglobin, and G6PD phenotypes. The material comprised 237 samples from the Nuba mountains, 330 samples from the Gabel Merah mountains, 401 samples from Khartoum, and 234 samples from Nilgiris, India.

A subsample of 296 male subjects from the Sudan was quantified for both red cell acid phosphatase and G6PD activities. The methods of qualitative typing by starch-gel electrophoresis for acid phosphatase, haemoglobin, haptoglobin, and G6PD have been described earlier. ${ }^{15}$ The procedure for red cell G6PD assay has been described elsewhere. ${ }^{16}$ Red cell acid phosphatase activity was determined by a standard procedure using p-nitrophenyl phosphate as the substrate and expressed in $\mu \mathrm{mol}$ p-nitrophenol liberated in half an hour per $g$ haemoglobin at $37^{\circ} \mathrm{C}$. 

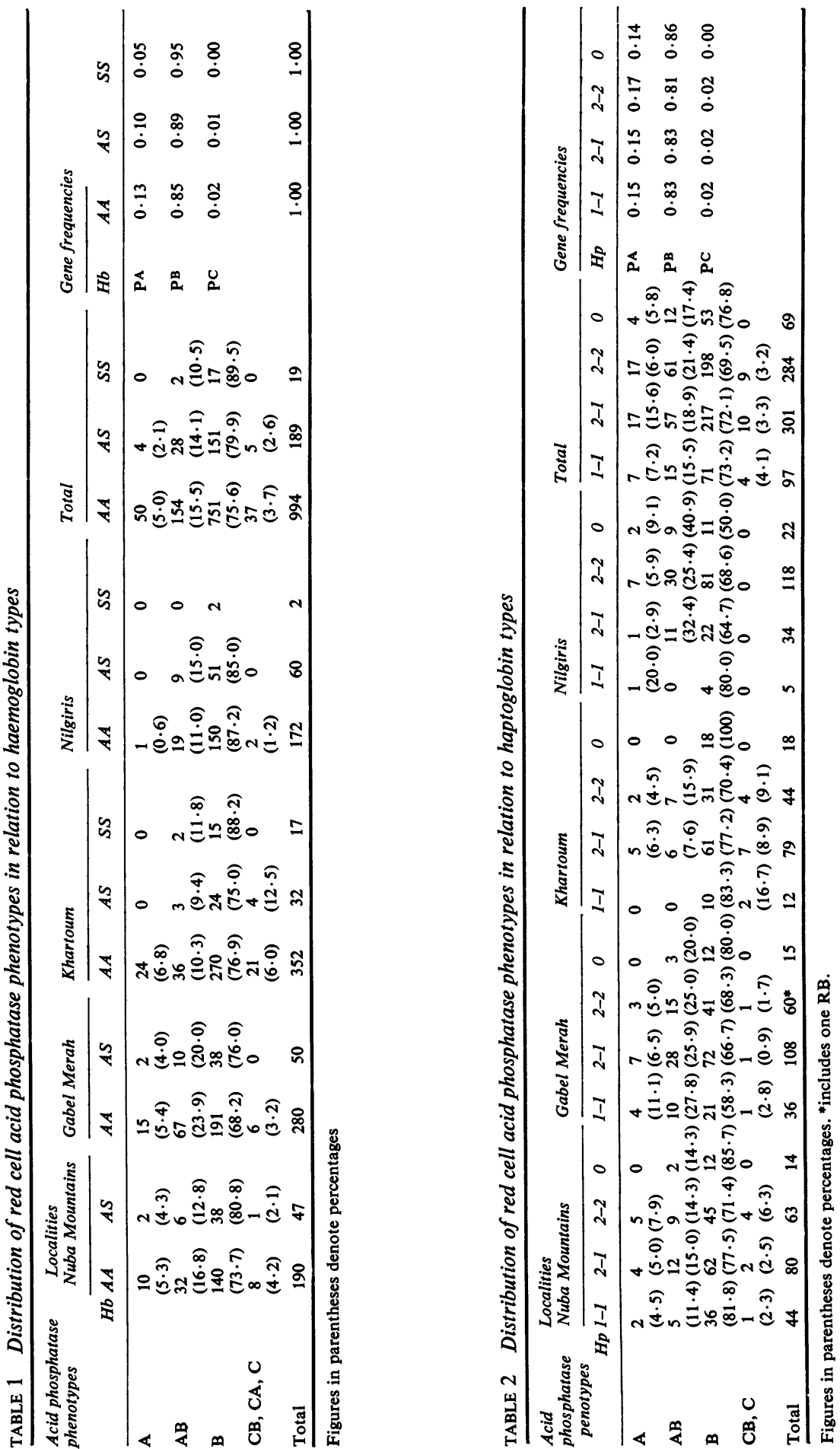


\section{Results and discussion}

\section{ACID PHOSPHATASE TYPES IN RELATION} TO HAEMOGLOBIN TYPES

The phenotypic distribution of red cell acid phosphatase in subjects with different types of haemoglobin (AA, AS, SS) in three groups from the Sudan and one group from Nilgiris, India, is presented in table 1. There was no significant difference in the distribution of red cell acid phosphatase types according to the type of haemoglobin in a total sample of 1202 . To our knowledge there has been no study reported which has examined the association of acid phosphatase types with different haemoglobin types.

The association of the sickle cell gene with malaria is well-documented, ${ }^{1}$ whereas that of red cell acid phosphatase polymorphism is disputed ${ }^{9} 10$ Therefore the lack of association of red cell acid phosphatase polymorphism with the sickle cell gene in the present investigation is compatible with the above.

\section{ACID PHOSPHATASE PHENOTYPES IN}

\section{RELATION TO HAPTOGLOBIN TYPES}

The distribution of red cell acid phosphatase phenotypes in subjects with different haptoglobin types in populations from three localities in the Sudan and from Nilgiris in India is presented in table 2. The gene frequencies of haptoglobins vary in different populations and the $\mathrm{Hp}$ ' $\mathrm{O}$ ' phenotype has been reported with a high frequency in African populations. Hp ' $\mathrm{O}$ ' phenotype has been claimed to have an acquired origin and is related to the haemolytic diseases. In general, the frequency of $\mathrm{Hp}^{\mathbf{1}}$ is higher in populations where the incidence of malaria was high in the past. The present study shows that the distribution of red cell acid phosphatase types is similar in relation to the haptoglobin phenotypes in all the four population groups.
ACID PHOSPHATASE TYPES IN RELATION TO G6PD TYPES

The distribution of red cell acid phosphatase types in relation to G6PD types in male subjects from the Sudan and Nilgiris is presented in table 3. Females have been excluded because of the difficulty in determining the G6PD phenotypes. Owing to the small number of uncommon variants in the three population groups of the Sudan, they have been combined. No significant difference in the distribution of red cell acid phosphatase types was observed in subjects with different G6PD types in the Sudanese sample, whereas there was a lack of AB phenotypes of acid phosphatase $\left(\chi^{2}=3.9\right)$ and lack of $\mathrm{PB}^{\mathrm{B}}$ in $\mathrm{Gd}^{\mathrm{B}-}$ in the Nilgiris population. Such an association in one population may be a chance occurrence. This observation is in agreement with the reported association of $P^{A}$ and favism. ${ }^{78}$ The frequency of $\mathrm{PC}^{\mathrm{C}}$ was very low in the present populations, so a large sample needs to be investigated to find any association. Furthermore, the most common G6PD deficiency is $\mathrm{Gd}^{\mathrm{A}-}$ rather than $\mathrm{Gd}^{\mathrm{B}-}$ in African populations and favism is uncommon in $\mathrm{Gd}^{\mathrm{A}}$ subjects. Bottini et $a l^{78}$ observed this association of red cell acid phosphatase and G6PD only in the deficient subjects with favism. Moreover, the population of the Sudan has a high degree of inbreeding which may complicate the expression of these genes, as reported in the Sardinian population. ${ }^{17}$

RED CELL ACID PHOSPHATASE ACTIVITY IN DIFFERENT ACID PHOSPHATASE, HAEMOGLOBIN, HAPTOGLOBIN, AND G6PD PHENOTYPES

The activity of red cell acid phosphatase in different phenotypes in 296 subjects from the Sudan is presented in table 4 and the figure. The levels of acid phosphatase activity in $\mathrm{IU} / \mathrm{g}$ haemoglobin in

TABLE 3 Distribution of red cell acid phosphatase phenotypes in relation to G6PD types (males only)

\begin{tabular}{|c|c|c|c|c|c|c|c|c|c|c|}
\hline \multirow{2}{*}{$\begin{array}{l}\text { Acid } \\
\text { phosphatase } \\
\text { phenotypes }\end{array}$} & \multicolumn{10}{|c|}{ G6PD phenotypes } \\
\hline & $\begin{array}{l}\text { Sudan } \\
A+\end{array}$ & $B+$ & $A+\& B+$ & $A-$ & $B-$ & $G d-$ & $G d^{i n t}$ & $\begin{array}{l}\text { All } \\
\text { deficients }\end{array}$ & $\begin{array}{l}\text { Nilgiris } \\
B+\end{array}$ & $B-$ \\
\hline A & $\begin{array}{l}1 \\
(2 \cdot 3)\end{array}$ & $\begin{array}{l}25 \\
(5 \cdot 5)\end{array}$ & $\begin{array}{l}26 \\
(5 \cdot 2)\end{array}$ & $\mathbf{0}$ & 2 & 4 & 1 & $\begin{array}{l}7 \\
(6 \cdot 6)\end{array}$ & $\begin{array}{l}3 \\
(2 \cdot 8)\end{array}$ & $\begin{array}{l}4 \\
(14 \cdot 8)\end{array}$ \\
\hline $\mathbf{A B}$ & $\begin{array}{l}6 \\
(14 \cdot 0)\end{array}$ & $\begin{array}{l}62 \\
(13.6)\end{array}$ & $\begin{array}{l}68 \\
(13 \cdot 6)\end{array}$ & 0 & 7 & 8 & 4 & $\begin{array}{l}19 \\
(17.9)\end{array}$ & $\begin{array}{l}32 \\
(29.9)\end{array}$ & $\begin{array}{l}3 \\
(11 \cdot 1)\end{array}$ \\
\hline B & $\begin{array}{l}35 \\
(81 \cdot 4)\end{array}$ & $\begin{array}{l}337 \\
(73.9)\end{array}$ & $\begin{array}{l}372 \\
(74 \cdot 5)\end{array}$ & 1 & 11 & 36 & 29 & $\begin{array}{l}77 \\
(72 \cdot 6)\end{array}$ & $\begin{array}{l}72 \\
(67 \cdot 3)\end{array}$ & $\begin{array}{l}20 \\
(74 \cdot 1)\end{array}$ \\
\hline $\mathrm{CB}, \mathrm{CA}, \mathrm{C}$ & $\begin{array}{l}1 \\
(2 \cdot 3)\end{array}$ & $\begin{array}{l}30 \\
(6 \cdot 6)\end{array}$ & $\begin{array}{l}31 \\
(6 \cdot 2)\end{array}$ & 1 & $\mathbf{0}$ & $\mathbf{0}$ & 2 & $\begin{array}{l}3 \\
(2 \cdot 8)\end{array}$ & & \\
\hline Total & 43 & 456 & 499* & 2 & 20 & 48 & 36 & 106 & 107 & 27 \\
\hline
\end{tabular}

*includes one each of DB and RB

Figures in parentheses denote percentages 
TABLE 4 Enzyme activity* of red cell acid phosphatase phenotypes

\begin{tabular}{lrl}
\hline Phenotypes & $n$ & Enzyme activity \\
\hline A & 19 & $111 \cdot 79 \pm 54 \cdot 14$ \\
AB & 47 & $112 \cdot 83 \pm 75 \cdot 67$ \\
B & 217 & $134 \cdot 88 \pm 75 \cdot 67$ \\
CB & 10 & $142 \cdot 65 \pm 96 \cdot 55$ \\
C & 1 & 70 \\
RB & 1 & 230 \\
DB & 1 & 100 \\
Total & 296 & $130 \cdot 14 \pm 93 \cdot 06$ \\
\hline
\end{tabular}

* $\mu \mathrm{mol}$ p-nitrophenol released in $0.5 \mathrm{~h}$ per $\mathrm{g}$ haemoglobin

different phenotypes are comparable with those in English and Italian populations. ${ }^{56}$ The frequency distribution of the enzyme activity in the most common phenotype (B) is slightly positively skewed (figure).

The red cell acid phosphatase activity in different haemoglobin, haptoglobin, and G6PD phenotypes is presented in table 5 . The enzyme activity is raised in the presence of a raised level of haemoglobin $\mathbf{A}_{2}$ and in sickle cell anaemia, but the difference is not significant in either case because of the small size of the sample. The presence of sickle cell trait did not alter the level of acid phosphatase. The results suggest that the change in activity of acid phosphatase is not because of the presence of thalassaemia. The red cell acid phosphatase activity in subjects with different haptoglobin phenotypes showed an insignificant higher level of enzyme activity in $\mathrm{Hp}^{2}$. $\mathrm{Hp}^{0}$ had a lower level of acid phosphatase activity, which suggests a probable role of acid phosphatase in the maintenance of the structural integrity of the red cell membrane, thereby preventing haemolysis.

G6PD deficient male Sudanese had a lower level of red cell acid phosphatase activity compared with normal subjects, but the difference is not statistically

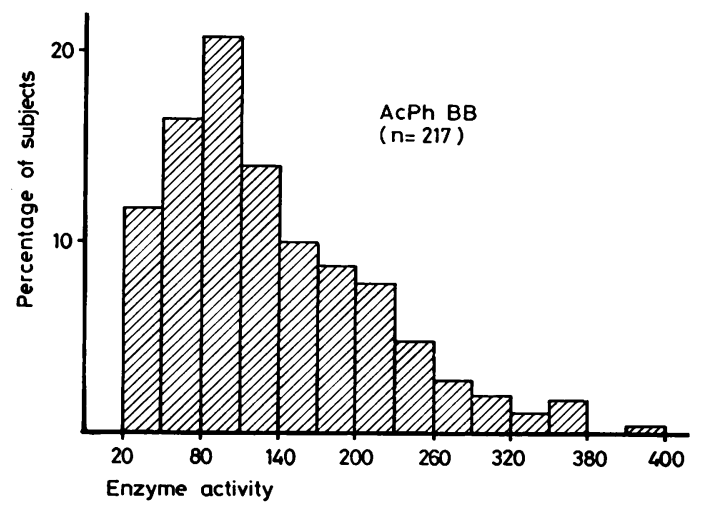

FIGURE Frequency distribution of the enzyme activity in $B$ phenotype of acid phosphatase.
TABLE 5 Red cell acid phosphatase activity* in relation to haemoglobin, haptoglobin, and G6PD types

\begin{tabular}{lrl}
\hline Phenotypes & \multicolumn{1}{c}{$n$} & Acid phosphatase \\
\hline Hb AA & 241 & $129 \cdot 94 \pm 76 \cdot 43$ \\
Hb AA & 5 & $149 \cdot 40 \pm 66 \cdot 45$ \\
Hb AS & 72 & $117 \cdot 69 \pm 65 \cdot 30$ \\
Hb SS & 1 & $158 \cdot 43 \pm 54 \cdot 65$ \\
Hb AF & 1 & $120 \cdot 00$ \\
Hb AO & & $201 \cdot 00$ \\
Hp 1-1 & 30 & $105 \cdot 37 \pm 63 \cdot 72$ \\
Hp 2-1 & 84 & $107 \cdot 29 \pm 61 \cdot 38$ \\
Hp 2-2 & 41 & $124 \cdot 05 \pm 57 \cdot 97$ \\
Hp 0 & 14 & $108 \cdot 29 \pm 69 \cdot 63$ \\
GdA & 19 & $132 \cdot 94 \pm 69 \cdot 58$ \\
GdB & 196 & $131 \cdot 15 \pm 76 \cdot 68$ \\
Gd int & 23 & $143 \cdot 48 \pm 79.40$ \\
Gd Khartoum & 3 & $139 \cdot 33 \pm 95 \cdot 27$ \\
Gd- & 48 & $105 \cdot 56 \pm 60 \cdot 20$ \\
\hline
\end{tabular}

Correlation of AP and G6PD activities: $r=0.1324 .{ }^{*} \mu \mathrm{mol} p$ nitrophenol released in $0.5 \mathrm{~h}$ per $\mathrm{g}$ haemoglobin

significant. This is in agreement with earlier reports of decreased activity in G6PD deficient Caucasians and Greeks. ${ }^{11-14}$ However, it is contrary to the reported raised levels of acid phosphatase in $\beta$-thalassaemia and G6PD deficient Romans and Sardinians. ${ }^{614}$ In the Italian population, a raised level of the enzyme activity was present in G6PD deficient subjects when it was associated with $\beta$-thalassaemia. This suggests that the effect is the result of the presence of thalassaemia rather than the G6PD deficiency in the Italians. The level of the acid phosphatase was higher in the presence of a raised level of $\mathrm{Hb} \mathrm{A}_{2}$ in this population also. This apparent discrepancy may be because G6PD deficiency in African populations and in the Sudan is mostly of the Negro type $\left(\mathrm{Gd}^{\mathrm{A}-}\right)$, whereas the deficiency in the Mediterranean is the result of $\mathrm{Gd}^{\mathrm{B}-}$, or the differential expression in different populations. Furthermore, the phenotypic association of acid phosphatase was observed only in cases of G6PD deficiency with favism in the Italian sample. There was a poor positive correlation of red cell acid phosphatase and G6PD activities $(r=0 \cdot 13)$. This differential selective adaptability of different genes in different populations of the world in response to different environmental conditions such as temperature, humidity, radiation, infective diseases, etc, may be responsible for the conflicting results of the association of G6PD deficiency and other abnormal haemoglobins with past malarial mortality and morbidity.

\section{References}

1 Allison AC. Polymorphism and natural selection in human populations. Quant Biol 1964; $29: 137-49$.

2 Haldene JBS. Natural selection in man. Acta Genet 1956; 6:321-32. 
${ }^{3}$ Saha N, Benerjee B. Erythrocyte G6PD deficiency in Chinese and Malays of Singapore. Trop Geogr Med 1971; 23:141-4.

${ }^{4}$ Hopkinson DA, Spencer N, Harris H. Red cell acid phosphatase variants: a new human polymorphism. Nature 1963;199:969-71.

5 Spencer N, Hopkinson DA, Harris H. Quantitative differences and genes dosage in the human red cell acid phosphatase polymorphism. Nature 1964;201:299-300.

6 Modiano G, Filippi G, Brunelli F, et al. Red cell acid phosphatase activity in carriers of $\beta$-thalassaemia and glucose-6-phosphatase dehydrogenase deficiency. Isr $J$ Med Sci 1968;4:856-66.

7 Bottini E, Lucarelli P, Agostino R, et al. Favism: association with erythrocyte acid phosphatase phenotypes. Science 1971; 171 : 409-11.

8 Bottini E, Lucarelli P, Bastianon V, Gloria F. Erythrocyte acid phosphatase polymorphism and haemolysis. $J$ Med Genet 1972;9:434-5.

9 Palmarino R, Agostino R, Gloria F, et al. Red cell acid phosphatase: another polymorphism correlated with malaria? Am J Phys Anthropol 1975; 43: 177-86.

10 Modiano G, Filippi G, Brunelli F, et al. Studies on red cell acid phosphatase in Sardinia and Rome. Absence of correlation with past malarial morbidity. Acta Genet 1967; 17: 17-28.

11 Oski FA, Shahidi NT, Diamond LK. Erthyrocyte acid phosphomonoesterase in glucose-6-phosphate dehydrogenase deficiency in Caucasians. Science 1963;139: 409-11.

12 Choremis C, Kattamis C, Zannos-Mariolea L. Erythrocyte acid phosphomonoesterase in G6PD-deficient Greeks. Lancet $1964 ; \mathrm{i}: 108-9$.

13 Kattamis C, Zannos-Mariolea L. Acid phosphatase activity in G6PD-deficient Greeks. Proc 10th Congr Int Soc Blood Transf, Stockholm, 1965: 603.

14 Schettini F, Meloni T, Mela C, Fanciulli G. Red cell acid phosphatase in normal and G6PD-deficient Sardinian subjects. Acta Haematol 1965; 33: 230-6.

15 Saha N, Samuel APW, Omer A, et al. A study of some genetic characteristics of the population of the Sudan. Ann Hum Biol 1978; 5: 569-75.

16 Samuel APW, Saha N, Omer A, Hoffbrand AV. Quantitative expression of G6PD activity in different G6PD and haemoglobin types in a Sudanese population. Hum Hered (in press).

17 Workman PL, Lucarelli P, Agostino R, et al. Genetic differentiation among Sardinian villages. Am J Phys Anthropol 1975; 43:165-76.

Requests for reprints to Professor N Saha, Department of Medical Genetics, University of Umeå, S-901 85 Umeå, Sweden. 